\title{
Growth and nutrient accumulation in three peach rootstocks until the grafting stage
}

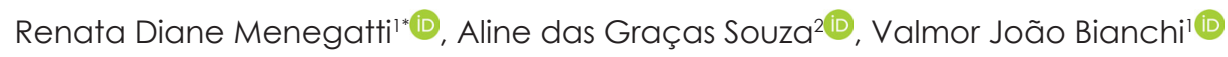 \\ 'Federal University of Pelotas, Capão do Leão, Brazil \\ ${ }^{2}$ Federal University of Paraíba, Areia, Brazil \\ *Corresponding author, e-mail: renata.d.menegatti@gmail.com
}

\begin{abstract}
Analysing growth and nutrient accumulation is generally employed for guiding the fertilisation practices in the seedling-production chain. In the production of peach rootstock, such evaluations can provide information to aid can to aid in discrimination available genotypes, especially regarding the efficient use and conversion of fertiliser into dry matter, which can reduce the time required to obtain plants suitable for grafting. The aim of this study, was to investigate the differences in growth and nutrient accumulation in three peach-rootstock cultivars. A completely randomised experimental design was used, in a $3 \times 4$ factorial scheme, including three peach rootstocks ('Flordaguard', 'Capdeboscq' and 'Okinawa Roxo') and four periods of growth evaluation (20, 40, 60 and 80 days after transplanting - DAT), giving a total of 12 treatments, with four replications, one for each plant. The Flordaguard and Capdeboscq cultivars showed greater height and stem diameter as well as a greater accumulation of total dry matter at 80 DAT, and both followed the distribution: leaves (67\%) > roots (33\%), while total dry-matter production in 'Okinawa Roxo' was less, following the order: leaves (71\%) > roots (29\%). The rootstock under evaluation showed variations in growth, confirmed by the physiological indices, except for the leaf area and specific leaf area. In general, macronutrient accumulation in the shoots and roots of the cultivars during each growth period was different, suggesting intrinsic differences in each of the genetic materials regarding nutrient demand for maintaining the metabolic processes which are vital to plant growth.
\end{abstract}

Keywords: physiological indices, plant nutrition, plant production, Prunus persica

\section{Introduction}

In the south of Brazil, the production of stonefruit seedlings, especially the peach, is still predominantly carried out within a traditional system, where rootstock is planted in the field from mid-April, so that the entire initial development of the plants takes place during the winter, resulting in slow growth and consequently increasing the time required to obtain rootstock suitable for grafting (Fischer et al., 2016). Furthermore, under such a system, grafting is carried out from November to January, 180-230 days after sowing (DAS). Due to the strong influence of the climate on plant growth, the production process ends at around 360 DAS, when grafted seedlings suitable for the market are obtained.

One promising alternative, already used in the southeast of the country to reduce the time spent on producing grafted peach seedlings, is the adoption of protected cultivation. This allows the optimum conditions for initial rootstock growth to be maintained, bringing the grafting period forward and reducing the production costs of keeping the seedlings in the nursery (Fachinello et al., 2011; Tomaz et al., 2014).

In order to guarantee that the plants express their vigour to the maximum in the shortest possible time, nutritional management practices, based on the efficient absorption, accumulation and conversion of nutrients into dry matter, are also commonly adopted (Fontes et al., 2013; Batista et al., 2015). Such techniques ensure an adequate supply of nutrients according to the nutritional efficiency of each genotype and/or cultivar, and promote the growth of plants of good nutritional status with maximum efficiency in the use of inputs, and optimise the financial resources spent on production (Carvalho et al., 2012; Fontes et al., 2013).

A variety of rootstock cultivars are currently available to fruit farmers for producing peach seedlings (Menegatti et al., 2019; Souza et al., 2019), however, no information is available regarding the differences in growth rates or their relationship with the efficiency of nutrient acquisition and accumulation over time. Such information, if recognised, could be used as additional criteria in selecting (Benincasa, 2003) rootstock to be 
introduced in improved production systems for peach seedlings.

The determination of growth rates and by monitoring nutrient accumulation when associated with the physiological needs of a given cultivar, the appropriate use of fertilisers can contribute to reducing the time required to obtain suitable seedlings for the market, supporting effective measures for short-term implementation by nurseries to improve seedling quality.

According to the need for improvements in the production chain of peach rootstock (Reis et al., 2010; Schmitz et al., 2014; Fischer et al., 2016) the aim of this study was to analyze the initial growth and accompany nutrient accumulation in three peach rootstocks until the grafting stage.

\section{Material and Methods}

The present study was conducted using propagation material from peach rootstock of the Flordaguard, Capdebosca and Okinawa Roxo cultivars, harvested between December 2016 and January 2017 from clonal parent plants of the peach rootstock germplasm collection at the Federal University of Pelotas (UFPel). The experiment was carried out under greenhouse conditions from April to August of 2017, where the mean daily temperature during the rootstock growth period (26 May to 14 August) was recorded for days after transplanting (DAT), and is shown in Figure 1.

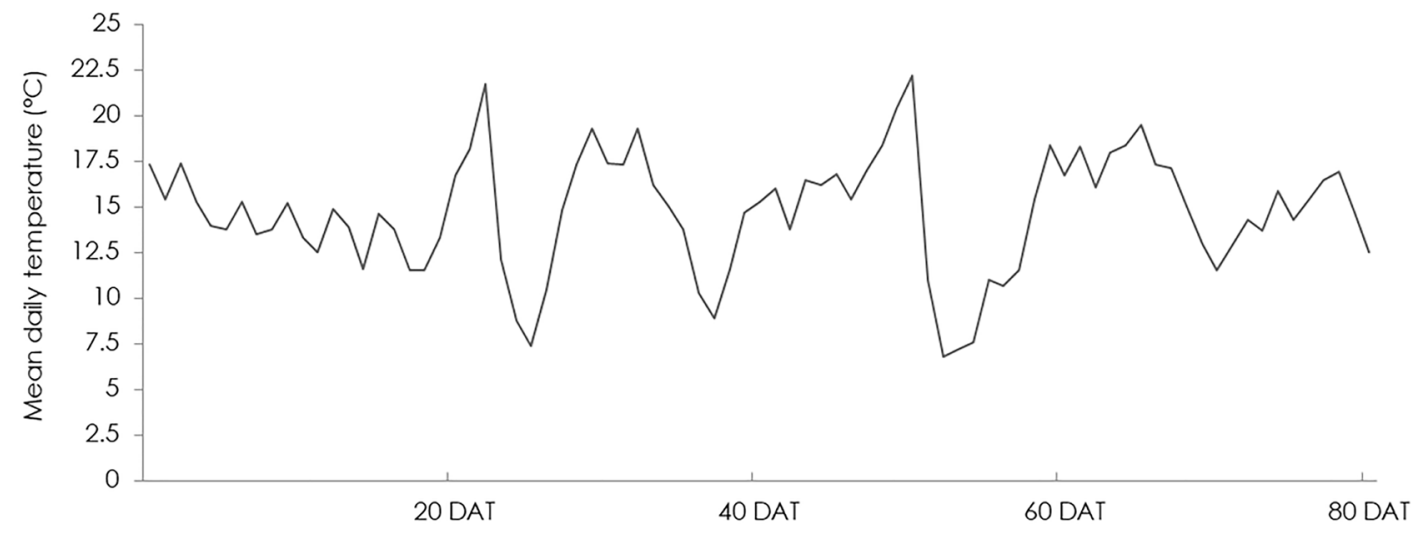

Figure 1. Mean daily temperature in the greenhouse during the rootstock growth period (May 26 to August 14), recorded for days after transplanting (DAT). Capão do Leão, Rio Grande do Sul, Brazil.

Once the fruit had been harvested, post-harvest management of the stones was carried, this was followed by the process of seed stratification, as recommended by Souza et al. (2017). After the period of stratification (35 days at $7^{\circ} \mathrm{C}$ ), the seeds were placed $1.0 \mathrm{~cm}$ deep in polystyrene trays of 72 cells ( $114 \mathrm{~cm}^{3}$ per cell) containing a substrate comprising a mixture of soil from the orchard + vermiculite + medium sand + Plantmax ${ }^{\circledR}$ commercial substrate (1:1:1:1), and kept in a greenhouse.

When the plants were ready for transplanting (a height of $15 \mathrm{~cm}$ from the stem to the apex) they were transferred into 1-litre plastic bags containing Carolina Soi ${ }^{\mathrm{B}}$ commercial substrate (called the Standard Commercial substrate), to which an $8 \mathrm{~g} \mathrm{~L}^{-1}$ dose of slow-release fertiliser capsules (Osmocote ${ }^{\circledR}$ ) at an NPK formulation of 14-14-14 had been added prior to transplanting.

The experimental design was completely randomised, in a $3 \times 4$ factorial scheme of three cultivars (Flordaguard, Capdebosca and Okinawa Roxo) and four growth periods $(20,40,60$ and 80 DAT), totalling 12 treatments, with four repetitions, each one consisting of four plants.
The following variables were evaluated for each growth period: shoot height $(H)$ (measured with a graduated rule), stem diameter (SD) $(10 \mathrm{~cm}$ from the plant stem, determined with a digital calliper) and leaf area (determined with a LI-COR ${ }^{\circledR}$ model LI-3100 portable area meter). The plants were then divided into roots, stems and leaves, and dried in a forced air circulation oven at $70^{\circ} \mathrm{C} \pm 5$ to constant weight, to determine the dry matter of the different parts of the plant: shoots (DSM), root (RDM) and total dry matter (TDM); the materials were then ground and stored.

The H, SD and dry matter data were submitted to analysis of variance (ANOVA); variables that presented a significant difference were submitted to regression analysis using the age of the plant expressed in DAT as the independent variable.

The N, P, K, Ca, Mg, S, B, Fe, Mn and Zn content of the plant material from the roots and shoots were then determined for each of the rootstock growth periods (DAT), using the methodology described by the Official Laboratory Network for Soil and Plant Tissue Analysis of Rio Grande do Sul (RS) and Santa Catarina (SC) - ROLAS 
(SBCS/CQFS, 2016). The nutritional data were analysed separately for each growth period, being submitted to analysis of variance by F-test with the mean values compared by Tukey's test at $5 \%$ probability. Statistical analysis of the data was carried out using the Sisvar statistical software package (Ferreira, 2011).

To obtain the physiological indices, the absolute growth rate (AGR), relative growth rate (RGR), leaf area (LA), net assimilation rate (NAR) and specific leaf area (SLA) were calculated by adjusting and determining the variables relative to time, with the aid of the ANACRES software (Portes \& Castro Júnior, 1991) using exponential quadratic equations. Because the data are calculated, the physiological indices do not obey the basic statistical assumptions for analysis of variance; the data were therefore presented in figure format, and the behaviour of the curves evaluated.

\section{Results and Discussion}

Analysis of the Growth Variables

From the analysis of variance, it could be seen that there was no significant interaction between the factors rootstock cultivar and growth period (DAT) for any of the growth variables under evaluation (Table 1), the effect of each factor was therefore evaluated separately.

Table 1. Summary of analysis of variance for the growth variables height (H), stem diameter (SD), shoot dry matter (SDM), root dry matter (RDM) and total dry matter in three peach rootstocks, as a function of the growth period (days after transplanting - DAT) in the greenhouse.

\begin{tabular}{|c|c|c|c|c|c|c|}
\hline \multirow{2}{*}{ Source of Variation } & \multirow{2}{*}{ DF } & \multicolumn{5}{|c|}{ Root Mean Square } \\
\hline & & $\mathrm{H}(\mathrm{cm})$ & $\mathrm{SD}(\mathrm{mm})$ & SDM (g) & RDM (g) & TDM (g) \\
\hline Cultivar (Cv) & 2 & $421.75^{* *}$ & $0.14^{* *}$ & $0.66^{* *}$ & $0.30^{* *}$ & $1.76^{* *}$ \\
\hline DAT (D) & 3 & $4561.81^{* *}$ & $4.68^{* *}$ & $16.28^{* *}$ & $2.81^{* *}$ & $32.38^{* *}$ \\
\hline$C V \times D$ & 6 & $11.53^{\text {ns }}$ & $0.25^{\mathrm{ns}}$ & $0.75^{\mathrm{ns}}$ & $0.14^{\mathrm{ns}}$ & $1.52^{\mathrm{ns}}$ \\
\hline Residue & 36 & 14.66 & 0.24 & 0.099 & 0.028 & 0.18 \\
\hline Mean & & 49.1 & 2.55 & 1.66 & 0.71 & 2.36 \\
\hline CV (\%) & & 7.8 & 19.14 & 19 & 23.51 & 17.89 \\
\hline
\end{tabular}

In relation to growth period, there was an increase in height and stem diameter, with the highest values reached at 80 DAT (Figure 2A and 2B). The peach rootstock of Flordaguard and Capdebosca cultivars showed superior growth for both variables, especially the

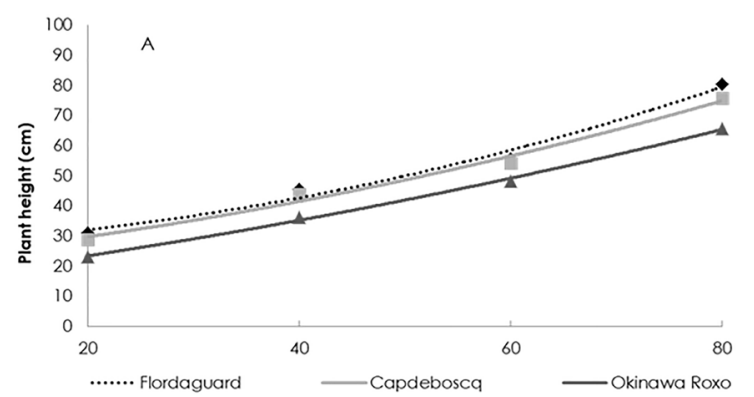

$\begin{array}{ccc}y=0,0065 x^{2}+0,1424 x+26,658 & y=0,0041 x^{2}+0,3393 x+21,34 & y=0.0027 \times 2+0.4255 x+1 \\ R^{2}=0,9855 & R^{2}=0,9894 & 0.9978\end{array}$

Figure 2. Height and stem diameter in peach rootstock of the Flordaguard, Capdebosca and 'Okinawa Roxo cultivars, as a function of the growth period (days after transplanting - DAT) in the greenhouse.

Using the traditional system of producing peach seedlings in the field, sowing in mid-May, obtained rootstock of the Capdebosca cultivar suitable for grafting ( $5 \mathrm{~mm}$ in diameter at $10 \mathrm{~cm}$ from the ground) at 240 DAS (Fischer et al., 2016). Schmitz et al. (2014), evaluating peach-rootstock production in the Capdebosca and Okinawa Roxo cultivars under three cultivation systems (in the field, on benches in the open and on benches in the greenhouse) and sown in commercial substrate in midJuly, were ready for grafting at 154 DAS, irrespective of the cultivation system. values for stemdiameter, of approximately $5.22 \mathrm{~mm}$ at 80 DAT, a diameter $12 \%$ greater than that obtained for the plants of the Okinawa Roxo cultivar, and enough for grafting (CESM, 1998).

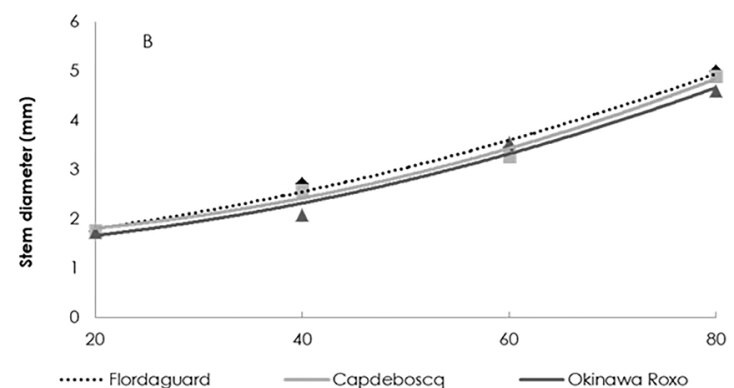

...... Flordaguard - Capdebosca Okinawa Roxo $0.004 x 2+0.0149 x+1.355 y=0,0005 \times 2-0,0005 x+1,6125 y=0,0004 x^{2}+0,0069 x+1,3525$ $R^{2}=0.99$

Considering the period after sowing, the rootstock in the present study was ready for grafting at 104 DAS, a shorter period than that obtained by Schmitz et al. (2014) and Fischer et al. (2016), suggesting that the reduced time taken for the rootstock to reach the grafting stage may have been the result of fertilisation by the commercial substrate, a factor that distinguished the present study from the above-mentioned studies, and which probably promoted the growth in CD.

According to Machado et al. (2011), the great majority of commercial substrates have small 
concentrations of nutrients considered essential to plant growth and development, which are rapidly exhausted, therefore making it necessary to add fertilisers, so that the plants can maximise their growth in the shortest possible time.

In each growth period (DAT), the shoot (SDM) and root (RDM) dry matter of the rootstock varied according to the cultivar under evaluation (Figure 3A). 'Flordaguard' and 'Capdeboscq' showed uniform SDM and RDM

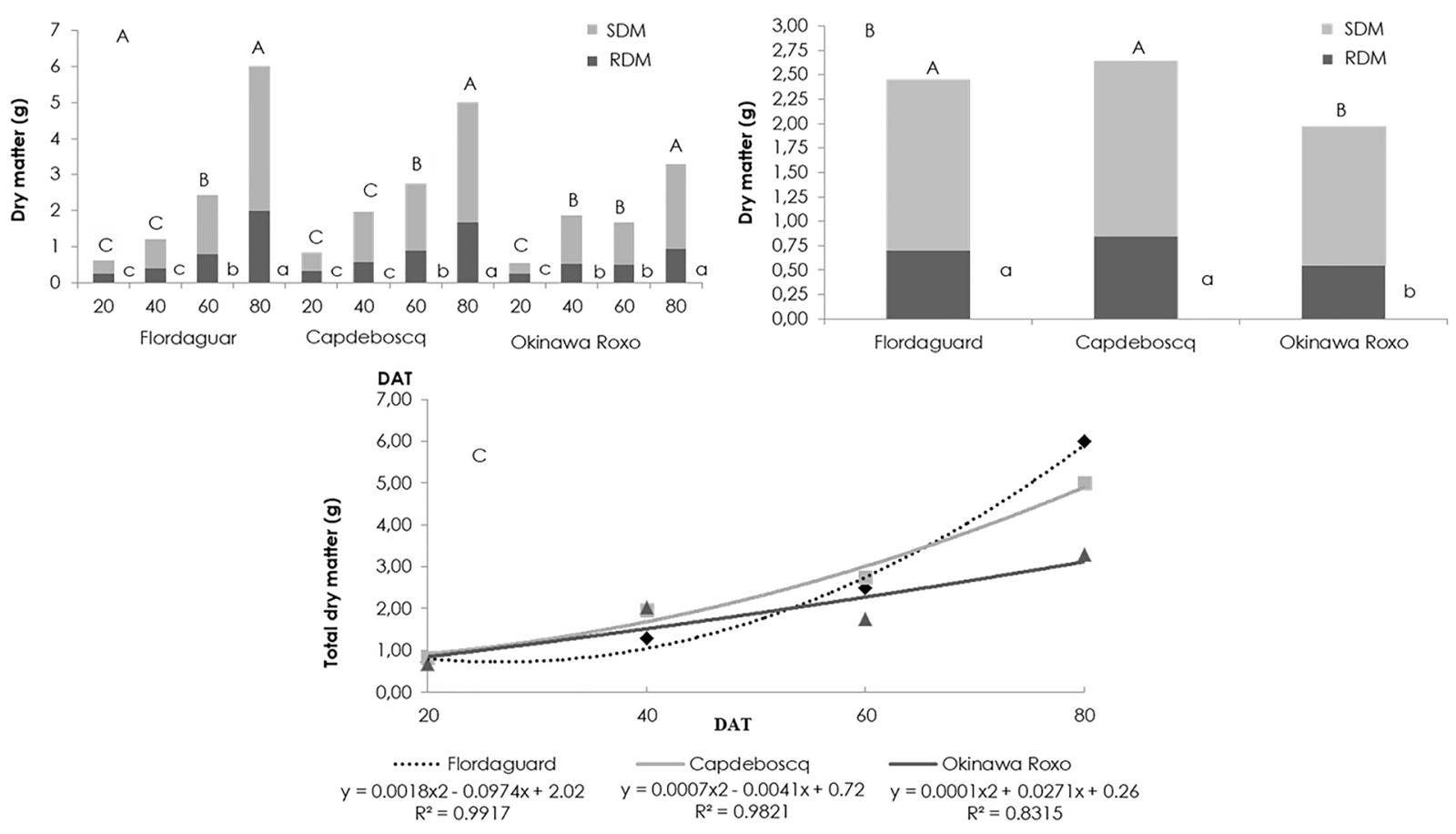

Figure 3. Shoot (SDM) and root (RDM) dry-matter production in peach rootstock of the Flordaguard, Capdebosca and Okinawa Roxo cultivars as a function of growth period (days after transplanting - DAT) (A), cultivars (B) and total dry matter (C). Mean values followed by the same lowercase letters between RDM within each cultivar, and by uppercase letters between SDM within each cultivar, do not differ by Tukey's test at $5 \%$ probability.

In general, during the first 20 DAT, the proportion of SDM to RDM remained practically the same; however, from 40 DAT it was possible to see a decreasing trend in dry mass distribution to the roots, irrespective of the cultivar under evaluation.

The results show that during the earliest DAT the rootstock tend to invest more energy in root production, with the aim of increasing the area for nutrient absorption. The plant then tends to change assimilate partitioning, i.e. the preferred drains for the consumption and storage of mineral nutrients and photoassimilates become those present in the shoots, such as the stems and expanding leaves, culminating during the growth stages of the plant in a greater accumulation of SDM (Epstein \& Bloom, 2005), as seen in the rootstocks from 40 DAT.

The extremely low accumulation of RDM and SDM up to 40 DAT, and the subsequent marked increase in production, may have occurred due to the low temperatures (Figure 1) recorded during the production over 40 DAT, with an increase in production at 60 days, culminating in maximum accumulation of the two variables at 80 DAT. Whereas the Okinawa Roxo cultivar showed a significant accumulation of SDM and RDM between 20 and 40 DAT, followed by a slow and insignificant increase between 40 and 80 DAT, demonstrating slower initial growth compared to the other cultivars and, consequently, less dry-matter accumulation at 80 DAT.

first period of plant growth, of approximately $13{ }^{\circ} \mathrm{C}$. The low temperatures cause a reduction in stomatal conductance, reducing internal $\mathrm{CO}_{2}$ concentration, which limits the maintainance of high carboxylation rates and photosynthetic efficiency (Machado et al., 2013). Because of the reduction in these physiological processes, the plant tends to reduce the production and accumulation of photoassimilates (Taiz et al., 2017), exactly as seen in the results of the present study, where the plants showed lower SDM and RDM accumulation, irrespective of the cultivar.

In addition, mild temperatures, together with a reduction in luminosity caused by the decline in photoperiod during rootstock growth (26 May to 14 August) tend to cause changes in the water status of the plant shoots due to a decrease in evaporative demand, which reduces the absorption of water and nutrients, both indispensable factors in maintaining and forming the constituents of the photosynthetic and respiratory 
metabolic processes that determine the capacity for maximizing growth (Chu et al., 2011).

Considering each cultivar separately, 'Capdeboscq' and 'Flordaguard' showed greater SDM production (1.79 and $1.75 \mathrm{~g} \mathrm{plant}^{-1}$, respectively), followed by 'Okinawa Roxo' (1.42 $\mathrm{g} \mathrm{plant}^{-1}$ ) (Figure $3 B$ ), with the same behaviour being seen for the RDM variable. According to the literature, 'Capdeboscq' is characterised by high initial vigour, which has helped promote and sustain its use in rootstock production for obtaining stone-fruit seedlings in Brazil (Schmitz et al., 2014; Souza et al., 2018).

The Flordaguard cultivar is considered promising material and is currently recommended for use in the production of peach rootstock, as it is immune to Meloidogyne incognita, a phytonematoid of high incidence in the orchards of southern Brazil (Mayer et al., 2015), and as it has seeds of superior vigor, which can ensure maximum initial plant growth (Souza et al., 2018; Menegatti et al., 2019).

In relation to total dry-matter production (Figure $3 \mathrm{C})$, by the end of the experiment the Flordaguard and Capdeboscq cultivars accumulated 6.03 and $4.99 \mathrm{~g}$ per

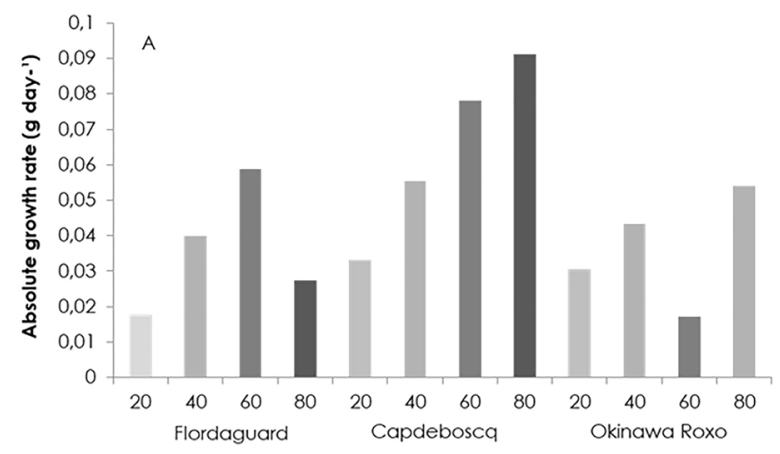

DAT

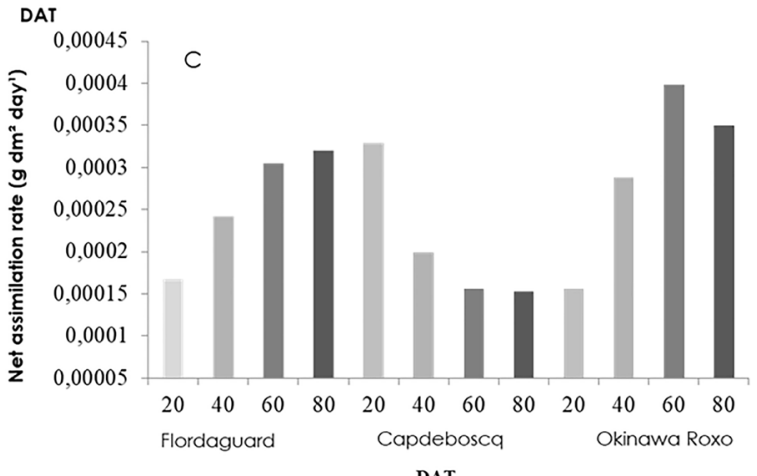

DAT plant respectively, and both followed the order, leaves $(67 \%)>$ roots (33\%); while total dry-matter production in the Okinawa Roxo cultivar by the end of the experiment was $3.29 \mathrm{~g}$ per plant, following the order, leaves $(71 \%)>$ roots (29\%). As mentioned above, irrespective of the cultivar, the shoots, among the plant organs, accumulated the greatest amount of dry matter, due to the leaves and branches being the largest drains for assimilates during the initial growth stage, possibly in order to increase leaf area, and maintain and produce photoassimilates for plant growth and development (Epstein \& Bloom, 2005).

As for the physiological indices, the plants of the Capdebosca rootstock showed a continuous increase in absolute growth rate (AGR), reaching a maximum at 80 DAT (0.091 $\mathrm{g} \mathrm{plant}^{-1}$ day $^{-1}$ ), while for the Flordaguard cultivar, the AGR showed similar behaviour to the Capdebosca cultivar, but with a maximum at 60 DAT (0.058 $\left.\mathrm{g} \mathrm{day}^{-1}\right)$ followed by a reduction (Figure 4A). The Okinawa Roxo cultivar showed a continuous increase during the first 40 DAT, with a decrease at 60 DAT and a second peak during the last evaluated growth period, 80 DAT, when it had the highest rate $\left(0.054 \mathrm{~g} \mathrm{day}^{-1}\right)$.

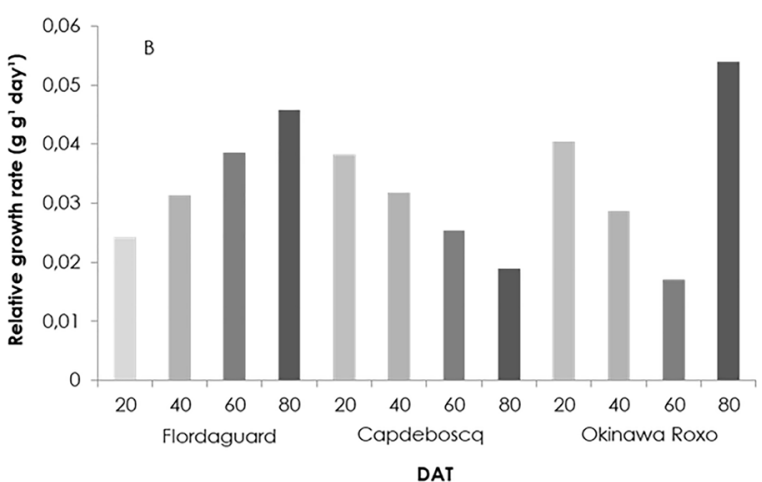

DAT

Figure 4. Absolute growth rate $\left(\mathrm{g}^{-1} \mathrm{day}^{-1}\right)(\mathrm{A})$, relative growth rate $\left(\mathrm{g} \mathrm{g}^{-1} \mathrm{day}^{-1}\right)(\mathrm{B})$ and net assimilation rate $\left(\mathrm{g} \mathrm{dm}^{-2} \mathrm{day}^{-1}\right)(\mathrm{C})$ in peach rootstock of the Flordaguard, Capdebosca and Okinawa Roxo cultivars for growth period (days after transplanting - DAT) in the greenhouse.

Since the AGR allows the average growth rate (g day ${ }^{-1}$ ) to be measured throughout the evaluation period, it should be noted that only the Capdebosca cultivar showed a continuous increasing trend in the rate throughout the growth of the plant, attributing this difference to the vigour shown by the cultivar, which, at 80 DAT, resulted in an AGR approximately twice as great as the other cultivars under evaluation. 
Higher values for relative growth rate (RGR) (Figure 4B) were found during the first growth period up to 20 DAT, with a subsequent systematic reduction up to 80 DAT for rootstock of the Capdebosca cultivar, suggesting that at the start of development the plants were composed of young leaves of high photosynthetic capacity, which promoted the rapid accumulation of biomass, a fact that again characterises the cultivar as of high initial vigour, as previously described by Schmitz et al. (2014) and Souza et al. (2018).

The reduction in AGR may have reflected an increase in respiratory activity, a fact that directs the carbon compounds produced during photosynthesis, and previously accumulated in the various plant organs, to maintaining the respiratory process (Chu et al., 2011).

The Flordaguard cultivar showed increasing values for RGR during the growth periods, reaching a maximum at 80 DAT, suggesting certain slowness in the development of these plants; while for the Okinawa Roxo cultivar there were two peaks in RGR, the first at 20 DAT and the second at 80 DAT.

Similar behavior to that of the RGR was obtained for the net assimilatory rate (NAR) (Figure 4C) for each

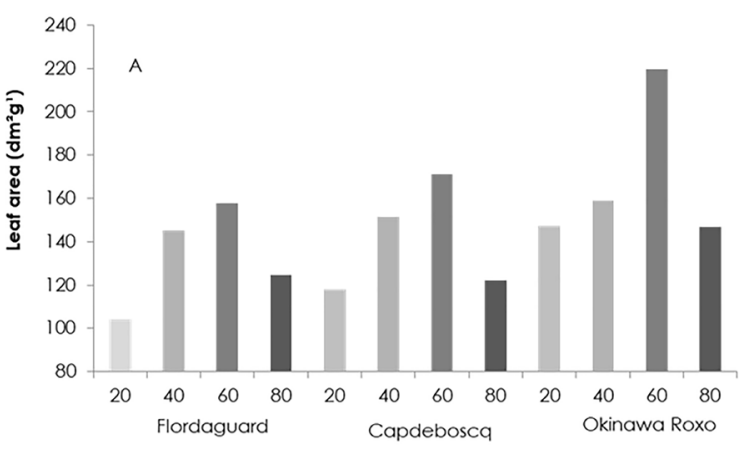
DAT of the cultivars under evaluation. The Flordaguard cultivar showed a continuous increase in NAR up to 80 DAT, contrary to the Capdebosca cultivar that showed a continuous reduction in this variable. The plants of the Okinawa Roxo cultivar showed an increase in NAR up to 60 DAT, followed by a decrease up to 80 DAT.

It is important to note that despite the high AGR shown by the Capdebosca cultivar, suggesting superior vigour at 80 DAT, this behavior occurred together with a reduction in RAR and NAR, which resulted in a lower production of total dry matter when compared to the Flordaguard cultivar. It is possible that to support a high AGR, the Capdebosca cultivar maintains higher transpiration rates than the Flordaguard cultivar, and to do this, allocates a greater amount of synthesized photoassimilates to maintaining respiration, reducing net photosynthesis, with a smaller increase in plant biomass, as shown for the TDM parameter at 80 DAT.

In general, the rootstock of each cultivar displayed a higher leaf area at 60 DAT (Figure 5A), these results agree with those reported in the literature for the LAR, which expresses the leaf area used in photosynthesis.

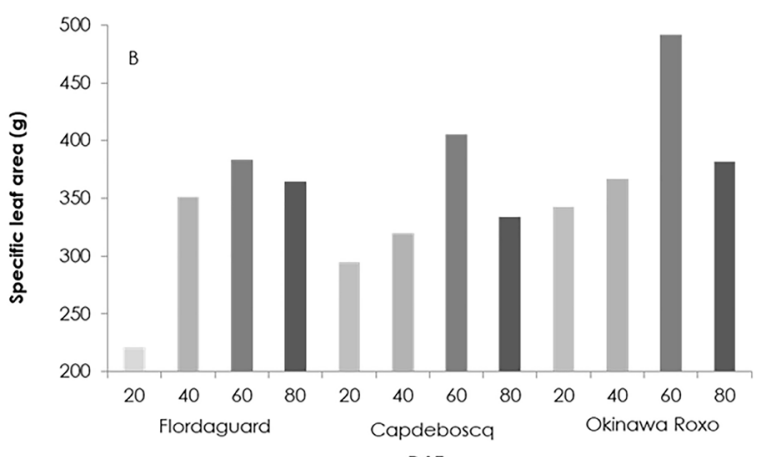

DAT

Figure 5. Leaf area $\left(\mathrm{dm}^{2} \mathrm{~g}^{-1}\right)(\mathrm{A})$ and specific leaf area (g) (B) in peach rootstock of the Capdeboscq, Flordaguard and Okinawa Roxo cultivars for growth period (days after transplanting - DAT) in the greenhouse

The great majority of plants show superior performance to that found for the cultivars in this study, i.e. they present a high LAR at the start of the cycle, the time when leaf development occurs to increase light absorption, which then decreases due to interference from the higher leaves on the lower leaves, a characteristic of self-shading (Benincasa, 2003), thereby reducing the leaf area used to carry out photosynthesis.

\section{Nutrient accumulation}

The macronutrient content of the shoots and roots was evaluated for the three peach rootstock cultivars during the growth periods (DAT) (Tables 2 and 3).

No differences were found between the various cultivars for nitrogen accumulation during the first two growth periods under evaluation (20 and 40 DAT) in either the shoots or roots (Table 2). However, at 60 and 80 DAT, differences between the rootstocks were seen for nitrogen accumulation in the shoots, with higher values recorded for the Flordaguard and Capdebosca cultivars.

The greater accumulation of $\mathrm{N}$ in the shoots of these cultivars may be related to the higher values seen for the variables $\mathrm{H}, \mathrm{CD}, \mathrm{SDM}$ and RDM, since this nutrient promotes an increase in the chlorophyll content of the leaves, increasing the light-absorbing capacity, resulting in a higher rate of carbon fixation and consequently an increase in carbohydrate production, which serves as a substrate for energy production and maintaining the plant growth rate (Bassi et al., 2018). 
Comparing each cultivar separately, a trend is seen towards a reduction in $\mathrm{N}$ accumulation throughout the growth periods of the plants, irrespective of the organ under evaluation. This can be explained both by the greater demand for this nutrient by the leaves, which in order to increase light capture and energy production is higher at the start of plant development (Bassi et al., 2018), and by the greater amount of $N$ available after application of the slow-release fertiliser, which may indicate a need for reapplication to meet the $\mathrm{N}$ demand of the plant.

Even with a non-significant trend for a reduction in $\mathrm{N}$ accumulation, values for leaf nitrogen remained within suitable levels for the crop according to SBCS/ CQFS (2016), suggesting that the dose used can be recommended in the fertilisation of peach rootstock for the period under evaluation.
According to criteria established by SBCS/CQFS (2016), phosphorus was the only nutrient accumulated in the shoots in a quantity considered above normal for all cultivars and all growth periods. Maximum accumulation was respectively 7.11 and $7.25 \mathrm{~g} \mathrm{~kg}^{-1}$ for the Capdebosca and Okinawa Roxo cultivars at 40 DAT, and $5.82 \mathrm{~g} \mathrm{~kg}^{-1}$ for 'Flordaguard' at 60 DAT.

The high concentration of $\mathrm{P}$ in the shoot and root tissue is probably due to the formulation of the fertiliser used (Osmocote ${ }^{\oplus}$, in the formulation NPK 14-14-14), which may have supplied more of this nutrient than demanded by the plant. It is worth noting that the nutrient source used has an equal amount of the three nutrients in its formulation, which reinforces the possibility of a greater dose of $\mathrm{P}$ than required by the plant being applied, especially considering that the demand of the plants for $N$ is greater than for the other nutrients.

Table 2. Macronutrient content of the shoots and roots (in $\mathrm{g} \mathrm{kg}^{-1}$ ) in peach rootstock of Capdeboscq, Flordaguard and Okinawa Roxo cultivars for growth period $(20,40,60$ and 80 days after transplanting) in the greenhouse.

\begin{tabular}{|c|c|c|c|c|c|c|c|c|c|c|c|c|}
\hline \multirow{3}{*}{ Cultivar } & \multicolumn{12}{|c|}{ Shoots } \\
\hline & \multicolumn{4}{|c|}{ N } & \multicolumn{4}{|c|}{$P$} & \multicolumn{4}{|c|}{ K } \\
\hline & 20 & 40 & 60 & 80 & 20 & 40 & 60 & 80 & 20 & 40 & 60 & 80 \\
\hline Flordaguard & $40.71 a$ & $38.32 a$ & $38.54 a$ & $35.33 a$ & $2.94 \mathrm{~b}$ & $4.62 \mathrm{~b}$ & $5.82 \mathrm{a}$ & $5.34 a$ & $13.61 a$ & $13.12 a$ & $13.91 a$ & $14.62 a$ \\
\hline Capdebosca & $37.73 a$ & $43.14 a$ & $36.71 a$ & $32.72 a$ & $5.08 \mathrm{a}$ & $7.11 \mathrm{a}$ & $5.97 \mathrm{a}$ & $5.73 a$ & $13.73 a$ & $13.51 a$ & $11.82 \mathrm{~b}$ & $14.40 a$ \\
\hline Okinawa Roxo & $34.47 a$ & $37.15 a$ & $31.92 \mathrm{~b}$ & $27.63 b$ & $4.71 \mathrm{a}$ & $7.25 a$ & $4.83 a$ & $5.07 a$ & $12.29 a$ & $12.67 a$ & $11.13 \mathrm{~b}$ & $15.81 a$ \\
\hline $\mathrm{F}$ & $1.97^{\mathrm{ns}}$ & $2.6^{\mathrm{ns}}$ & $5.76^{* *}$ & $5.16^{* *}$ & $1.05^{\text {ns }}$ & $7.26^{* *}$ & $2.08^{\text {ns }}$ & $2.35^{\text {ns }}$ & $0.97^{\mathrm{ns}}$ & $0.56^{\text {ns }}$ & $3.98^{* *}$ & $1.35^{\text {ns }}$ \\
\hline$C V(\%)$ & 11.84 & 10.06 & 8.24 & 25.1 & 24.5 & 17.49 & 15.52 & 8.34 & 11.55 & 8.69 & 11.70 & 9.03 \\
\hline \multirow{3}{*}{ Cultivar } & \multicolumn{12}{|c|}{ Roots } \\
\hline & \multicolumn{4}{|c|}{$\mathrm{N}$} & \multicolumn{4}{|c|}{$P$} & \multicolumn{4}{|c|}{ K } \\
\hline & 20 & 40 & 60 & 80 & 20 & 40 & 60 & 80 & 20 & 40 & 60 & 80 \\
\hline Flordaguard & $24.43 a$ & $21.72 a$ & $22.51 a$ & $19.91 a$ & $5.51 a$ & $4.72 \mathrm{~b}$ & $5.95 a$ & $5.90 a$ & $15.36 \mathrm{~b}$ & $13.15 b$ & $13.08 a$ & $11.17 a$ \\
\hline Capdeboscq & $28.41 a$ & $22.30 a$ & $18.39 b$ & $17.90 a$ & $4.87 a$ & $7.08 a$ & $5.14 b$ & $4.85 a$ & $17.27 a$ & $17.76 a$ & $12.94 a$ & $11.69 a$ \\
\hline Okinawa Roxo & $27.05 a$ & $22.21 a$ & $18.42 \mathrm{~b}$ & $18.73 a$ & $3.83 b$ & $5.67 \mathrm{~b}$ & $5.92 a$ & $5.36 a$ & $11.91 \mathrm{C}$ & $13.91 \mathrm{~b}$ & $13.23 a$ & $11.30 \mathrm{a}$ \\
\hline $\mathrm{F}$ & $0.27^{\text {ns }}$ & $0.30^{\text {ns }}$ & $18.02^{* *}$ & $3.29^{\text {ns }}$ & $13.56^{* *}$ & $31.17^{* *}$ & $14.73^{* *}$ & $1.39^{\text {ns }}$ & $175.36^{* *}$ & $40.98^{* *}$ & $0.13^{\text {ns }}$ & $1.66^{\mathrm{ns}}$ \\
\hline CV (\%) & 29.4 & 5.31 & 6.04 & 27.7 & 9.81 & 7.23 & 4.71 & 19.3 & 2.72 & 5.21 & 6.89 & 13.34 \\
\hline
\end{tabular}

Mean values followed by different letters in the same column differ by Tukey's test. "significant at $1 \%$ probability; nsnot significant. Interpretation of the results of the leaf analysis in the peach as per SBCS/CQFS (2016): $\square$ : below normal, : normal, $\square$ : above normal.

Table 3. Macronutrient content of the shoots and roots (in $\mathrm{g} \mathrm{kg}^{-1}$ ) in peach rootstock of Capdeboscq, Flordaguard and Okinawa Roxo cultivars for growth period $(20,40,60$ and 80 days after transplanting) in the greenhouse.

\begin{tabular}{|c|c|c|c|c|c|c|c|c|c|c|c|c|}
\hline \multirow{3}{*}{ Cultivar } & \multicolumn{12}{|c|}{ Shoots } \\
\hline & \multicolumn{4}{|c|}{$\mathrm{Ca}$} & \multicolumn{4}{|c|}{$\mathrm{Mg}$} & \multicolumn{4}{|c|}{$S$} \\
\hline & 20 & 40 & 60 & 80 & 20 & 40 & 60 & 80 & 20 & 40 & 60 & 80 \\
\hline Flordaguard & $4.99 a$ & $4.81 a$ & $5.83 b$ & $8.54 a$ & $4.94 a$ & $5.33 a$ & $4.92 b$ & $6.32 a$ & $2.01 \mathrm{c}$ & $1.84 a$ & $1.62 \mathrm{~b}$ & $1.73 b$ \\
\hline Capdebosca & $4.63 a$ & $5.60 a$ & $9.10 a$ & $9.80 a$ & $4.70^{a}$ & $6.21 a$ & $6.26 a$ & $7.61 a$ & $2.20 a$ & $1.76 c$ & $1.50 c$ & $1.54 \mathrm{c}$ \\
\hline Okinawa Roxo & $5.30 a$ & $5.55 a$ & $8.07 a$ & $8.51 a$ & $4.50 a$ & $5.73 a$ & $5.87 a$ & $7.00 a$ & $2.13 b$ & $1.79 \mathrm{~b}$ & $1.82 a$ & $2.09 a$ \\
\hline $\mathrm{F}$ & $0.86^{\mathrm{ns}}$ & $4.51^{* *}$ & $5.80^{* *}$ & $7.10^{* *}$ & $5.29 * *$ & $4.98^{* *}$ & $2.24^{* *}$ & $4.11^{* *}$ & $284.7^{* *}$ & $109.0^{* *}$ & $170.6^{* *}$ & $109.8^{* *}$ \\
\hline \multirow[t]{2}{*}{ CV (\%) } & 14.05 & 7.63 & 17.71 & 6.20 & 9.14 & 7.47 & 6.87 & 9.01 & 0.16 & 0.14 & 0.12 & 0.17 \\
\hline & \multicolumn{12}{|c|}{ Roots } \\
\hline \multirow[t]{2}{*}{ Cultivar } & \multicolumn{4}{|c|}{$\mathrm{Ca}$} & \multicolumn{4}{|c|}{$\mathrm{Mg}$} & \multicolumn{4}{|c|}{$S$} \\
\hline & 20 & 40 & 60 & 80 & 20 & 40 & 60 & 80 & 20 & 40 & 60 & 80 \\
\hline Flordaguard & $2.92 \mathrm{~b}$ & $1.80 \mathrm{c}$ & $1.80 \mathrm{~b}$ & $1.81 a$ & $2.75 b$ & $2.55 a$ & $2.66 a$ & $2.65 a$ & $2.08 \mathrm{c}$ & $1.80 a$ & $1.67 \mathrm{~b}$ & $1.69 \mathrm{~b}$ \\
\hline Capdebosca & $3.37 a$ & $2.61 a$ & $2.05 a$ & $1.84 a$ & $3.77 a$ & $2.80 a$ & $2.47 b$ & $2.77 a$ & $2.20 a$ & $1.66 \mathrm{c}$ & $1.59 \mathrm{C}$ & $1.52 \mathrm{C}$ \\
\hline Okinawa Roxo & $2.24 \mathrm{C}$ & $2.20 \mathrm{~b}$ & $1.47 \mathrm{c}$ & $1.80 a$ & $2.74 \mathrm{~b}$ & $2.34 a$ & $2.66 a$ & $2.30 \mathrm{a}$ & $2.11 \mathrm{~b}$ & $1.78 \mathrm{~b}$ & $1.83 a$ & $2.10 a$ \\
\hline $\mathrm{F}$ & $51.52^{* *}$ & $16.10^{* *}$ & $55.99^{* *}$ & $0.018^{\text {ns }}$ & $15.36^{* *}$ & $2.36^{\mathrm{ns}}$ & $3.84^{* *}$ & $1.38^{\mathrm{ns}}$ & $123.7^{* *}$ & $109.0^{* *}$ & $170.6^{* *}$ & $109.8^{* *}$ \\
\hline CV (\%) & 5.46 & 9.72 & 4.67 & 25.0 & 9.53 & 12.15 & 5.52 & 23.83 & 0.27 & 0.14 & 0.12 & 0.17 \\
\hline
\end{tabular}


According to Mayer et al. (2015), P is not a limiting factor in the development of peach rootstock, with phosphate fertilizers or formulations containing $P$ being unnecessary, and if applied, may result in leaf $P$ levels above the limit considered normal. In addition, it should be considered that conventional fertilisers have a greater $\mathrm{P}$ content due to immobilisation of a good part of the element to the soil particles, a situation that differs from the fertiliser used in the present study, in which the NPK 14-14-14 formulation contains the same amount of each element.

The Flordaguard cultivar was the only one to present normal levels of $\mathrm{K}$ in the shoots during each growth period, suggesting that the evaluated rootstock may present differences in the kinetic parameters of nutrient absorption, these being related to the morphological and physiological characteristics of the cultivar.

According to Viana \& Kiehl (2010), the K content of plants can stimulate nitrogen absorption and assimilation, and consequently, maximise use of this nutrient, which is described above as being fundamental to the maintenance and accumulation of dry matter, agreeing with the results obtained for TDM and for the physiological indices of this cultivar.

In general, analysis of macronutrient accumulation (N, P and $K$ ) in the shoots and roots during each growth period, suggests that the supplied dose of fertiliser results in different accumulations of these macronutrients between cultivars, possibly due to the intrinsic differences of each cultivar in nutrient demand for maintaining the metabolic processes vital to plant growth and development.

The three peach-rootstock cultivars under test showed maximum $\mathrm{Ca}$ accumulation at 20 DAT for the roots, and at 80 DAT for the shoots (Table 3). This behaviour may be related to the mobility of $\mathrm{Ca}$, which once absorbed, is simultaneously translocated for water displacement, a process determined by the rate of transpiration (Epstein \& Bloom, 2005), i.e. with the advance in plant growth and the increase in LAR and SLA, water loss through transpiration is greater, with the consequent displacement of $\mathrm{Ca}$ from the roots to the shoots and leaves (Epstein \& Bloom, 2005).

Similar results to those obtained for Ca were found for $\mathrm{Mg}$, while for sulphur, maximum accumulation occurred at 20 DAT in each cultivar, irrespective of the organ under evaluation.

The decreasing order of macronutrients accumulated in the shoots for 'Capdeboscq' and 'Okinawa Roxo' was: N>K>Ca>P>Mg$>\mathrm{S}$; however, for the Flordagard cultivar, it was: $\mathrm{N}>\mathrm{K}>\mathrm{Ca}>\mathrm{Mg}>\mathrm{P}>\mathrm{S}$. According to Fachinello et al. (2005), the decreasing order of macronutrients found in the present study for the Flordaguard cultivar refers to the ideal leaf content of a healthy peach plantlet, highlighting the possible relationship between ideal micronutrient accumulation in the shoots and the superiority of this cultivar in the growth variables under evaluation and the physiological indices obtained.

The decreasing order of macronutrients accumulated in the roots for each rootstock was $\mathrm{N}>\mathrm{K}>\mathrm{P}>\mathrm{Mg}>\mathrm{Ca}>\mathrm{S}$. The greater accumulation of $\mathrm{P}$ in the root system is important in this case, and the behaviour is different to that found in the shoots, where the nutrient occupies the 4th and 5th position in the order of accumulation. It is worth noting that, considering the criteria established by SBCS/CQFS (2016), P was the only nutrient accumulated in the shoots in a quantity considered above normal for all cultivars and all growth periods, with $P$ retention in the roots a plant strategy for avoiding $P$ toxicity of the shoots when the soil concentration of the nutrient is high (Taiz et al., 2017).

According to table 4, there were no significant differences in micronutrient content ( $\mathrm{B}, \mathrm{Fe}, \mathrm{Mn}$ and $\mathrm{Zn}$ ) for each rootstock under evaluation as a function of the growth period, irrespective of the organ. The leaf content of each micronutrient was classified as below normal according to SBCS/CQFS (2016), however, this result was to be expected, since micronutrient fertilisation was not carried out.

These results suggest that during the initial growth period, the plants absorb the maximum amount of nutrients available in the substrate, and that this seems to suppress plant demand for macro- and micronutrients until the plants are ready for grafting. However, to produce seedlings grafted from these rootstocks under the same cultivation system, a supply of micronutrients is necessary. This is because, after grafting, the shoots of the rootstock are cut and a new growth phase begins (graft growth), which coincides with the hottest times of the year, resulting in a greater demand for nutrients; if these are not supplied taking the physiological demand of each cultivar into consideration, graft growth and consequently the time necessary to obtain suitable seedlings for the market could be compromised. 
Table 4. Micronutrient content of the shoots and roots (in $\mathrm{g} \mathrm{kg}^{-1}$ ) in peach rootstock of Capdeboscq, Flordaguard and Okinawa Roxo cultivars for growth period (days after transplanting) in the greenhouse.

\begin{tabular}{|c|c|c|c|c|c|c|c|c|c|c|c|c|c|c|c|c|}
\hline \multirow{3}{*}{ Cultivar } & \multicolumn{16}{|c|}{ Shoots } \\
\hline & \multicolumn{4}{|c|}{$\mathrm{B}$} & \multicolumn{4}{|c|}{$\mathrm{Fe}$} & \multicolumn{4}{|c|}{$M n$} & \multicolumn{4}{|c|}{ Zn } \\
\hline & 20 & 40 & 60 & 80 & 20 & 40 & 60 & 80 & 20 & 40 & 60 & 80 & 20 & 40 & 60 & 80 \\
\hline Flordaguard 1 & $12.48 a$ & $10.7 a$ & $8.69 a$ & $5.58 a$ & $51.85 a$ & $53.08 a$ & $41.18 a$ & $66.79 a$ & $15.82 a$ & $15.99 a$ & a 15.52a & $25.69 a$ & $5.40 a$ & $6.90 a$ & $8.17 a$ & $9.52 a$ \\
\hline Capdebosca 1 & $12.00 a$ & $9.34 a$ & $7.39 a$ & $9.83 a$ & $71.82 \mathrm{a}$ & $55.69 a$ & $51.01 \mathrm{a}$ & $47.57 a$ & $15.50 a$ & $14.78 a$ & $24.23 a$ & $31.86 a$ & $5.82 a$ & $7.04 a$ & $6.36 \mathrm{~b}$ & $5.37 a$ \\
\hline Okinawa Roxol & $13.85 a$ & $8.93 a$ & $9.83 a$ & $16.14 a$ & $74.81 \mathrm{a}$ & $45.41 \mathrm{a}$ & $43.13 a$ & $76.67 a$ & $16.61 a$ & $18.46 a$ & $14.16 \mathrm{~b}$ & $35.50 a$ & $6.04 a$ & $7.20 a$ & $6.74 \mathrm{~b}$ & $5.78 a$ \\
\hline $\mathrm{F}$ & 1.05 & 0.150 & 1.410 & $6.81^{* *}$ & 0.69 & 0.99 & 0.83 & 0.68 & 2.47 & 0.65 & $12.92^{* *}$ & 2.71 & 0.50 & 0.21 & $7.09 * *$ & 3.15 \\
\hline \multirow[t]{2}{*}{$C \vee(\%)$} & 14.66 & 53.2 & 23.79 & 38.72 & 45.15 & 20.90 & 25.29 & 56.50 & 12.15 & 28.44 & 19.31 & 19.41 & 15.82 & 9.31 & 10.14 & 37.40 \\
\hline & \multicolumn{16}{|c|}{ Roots } \\
\hline \multirow[t]{2}{*}{ Cultivar } & \multicolumn{4}{|c|}{ B } & \multicolumn{4}{|c|}{$\mathrm{Fe}$} & \multicolumn{4}{|c|}{$\mathrm{Mn}$} & \multicolumn{4}{|c|}{ Zn } \\
\hline & 20 & 40 & 60 & 80 & 20 & 40 & 60 & 80 & 20 & 40 & 60 & 80 & 20 & 40 & 60 & 80 \\
\hline Flordaguard & $9.72 a$ & $10.5 a$ & $18.0 a$ & $15.28 a$ & $65.56 a$ & $49.50 a$ & $43.06 a$ & $41.39 a$ & $6.90 \mathrm{~b}$ & $9.67 a$ & $3.69 \mathrm{~b}$ & $3.95 b$ & $5.82 a$ & $4.17 c$ & $5.36 a$ & $4.88 a$ \\
\hline Capdebosca & $9.64 a$ & $12.1 a$ & $19.5 a$ & $19.08 a$ & $54.16 a$ & $55.10 a$ & $49.97 a$ & $40.16 a$ & $9.39 a$ & $10.68 a$ & $7.60 a$ & $5.37 b$ & $5.02 b$ & $5.95 a$ & $5.32 a$ & $4.04 a$ \\
\hline Okinawa Roxo & $10.1 a$ & $11.0 \mathrm{a}$ & $17.3 a$ & $11.80 a$ & $66.53 a$ & $53.41 \mathrm{a}$ & $49.45 a$ & $54.72 a$ & $2.89 \mathrm{c}$ & $9.62 a$ & $3.18 \mathrm{~b}$ & $10.83 a$ & $3.95 \mathrm{c}$ & $5.07 \mathrm{~b}$ & $4.25 b$ & $4.45 a$ \\
\hline $\mathrm{F}$ & 0.54 & 0.31 & 0.56 & 1.09 & $257.28^{* *}$ & $* 0.13^{* *}$ & 0.65 & 2.08 & $42.87^{* *}$ & 0.55 & $49.14^{* *}$ & $6.87^{* *}$ & $18.70^{* *}$ & $11.67^{* *}$ & $3.76^{* *}$ & 1.50 \\
\hline CV (\%) & 27.7 & 22.64 & 16.91 & 23.4 & 2.69 & 30.85 & 20.03 & 24.64 & 15.66 & 16.22 & 14.32 & 41.23 & 8.78 & 10.24 & 13.06 & 15.29 \\
\hline
\end{tabular}

The order for leaf micronutrient content found in the peach rootstock agrees with that of Fachinello et al. (2005), indicating that the ideal leaf content in a healthy peach seedling should follow Fe $>M n>B>Z n$.

From joint and comparative analysis of the data for growth and nutrient accumulation, it can be inferred that the peach-rootstock cultivars under evaluation display similar macro- and micronutrient accumulation, but behave differently during the initial growth phase and plant development, indicating probable differences in the use of these nutrients in increasing plant biomass. As such, a more in-depth investigation is suggested to verify whether such behaviour is maintained over time, especially from when these rootstocks are grafted until suitable plantlets are obtained for the market.

\section{Conclusions}

The Capdebosca and Flordaguard rootstocks are superior for the growth variables and physiological indices under evaluation, except for leaf area and specific leaf area.

In general, the accumulated macronutrient content, in both the shoots and roots for each growth period, differ between the evaluated genetic material. However for micronutrientes there are no differences.

The various rootstock cultivars have different strategies for absorbing and using mineral elements from the substrate, especially macronutrients, reflecting in differences in growth during the early stages of development.

\section{Acknowledgements}

This study was financed in part by the Coordenação de Aperfeiçoamento de Pessoal de Nível

\section{Superior (CAPES).}

\section{References}

Bassi, D., Menossi, M., Mattiello, L. 2018. Nitrogen supply influences photosynthesis establishment along the sugarcane leaf. Scientific reports 8: 23-27.

Batista, R.O., Furtini Neto, A.E., Deccetti, S.F.C. 2015. Eficiência nutricional em clones de cedro-australiano. Scientia Forestalis 43: 647-655.

Benincasa, M.M.P. 2003. Análise de crescimento de plantas: noções básicas. $2^{\text {nd }}$ ed. Fundação Nacional de Ensino e Pesquisa, Jaboticabal, Brazil. 41 p.

Carvalho, R.P., Von Pinho, R.G., Davide, L.M.C. 2012. Eficiência de cultivares de milho na absorção e uso de nitrogênio em ambiente de casa de vegetação. Semina: Ciências Agrárias 33: 2125-2136.

CESM. Comissão Estadual de Sementes e Mudas do Estado do Rio Grande do Sul. 1998. Normas e padrões de produção de mudas de fruteiras para o Estado do Rio Grande do Sul. CESM, Porto Alegre, Brazil. 100 p.

Chu, Z., Lu, Y., Chang, J., Wang, M., Jiang, H., He, J., Peng, C., Ge, Y. 2011. Leaf respiration/photosynthesis relationship and variation: an investigation of 39 woody and herbaceous species in east subtropical China. Trees 25: $301-310$.

Epstein, E., Bloom, A.J. 2005. Mineral Nutrition of Plants: Principles and Perspectives. $2^{\text {nd }}$ ed. Sinaver Associates, Inc., Sunderland, USA. 150 p.

Fachinello, J.C., Hoffmann, A., Nachtigal, J.C. 2005. Propagação de plantas frutíferas. Embrapa Informação tecnológica, Brasília, Brazil. 221 p.

Fachinello, J.C., Pasa, M.S., Schmtiz, J.D., Betemps, D.L. 2011. Situação e perspectivas de frutíferas de clima temperado no Brasil. Revista Brasileira de Fruticultura 33: 109-120. 
Ferreira, D.F. 2011. SISVAR: A computer statistical analysis system. Ciência e Agrotecnologia 35: 1039-1042.

Fischer, D.L.O., Picolotto, L., Rocha, M.S., Souza, A.G., Bianchi, V.J. 2016. Influência do período de estratificação em frio úmido sobre a emergência e produção de portaenxertos de pessegueiro a campo. Revista Congrega 1: $1-11$.

Fontes, A.G., Gama-Rodrigues, A.C., Gama-Rodrigues, E.F. 2013. Eficiência nutricional de espécies arbóreas em função da fertilização fosfatada. Pesquisa Florestal Brasileira 33: 9-18.

Machado, D.F.S.P., Ribeiro, R.V., Silveira, J.A.G., Magalhães Filho, J.R., Machado, E.C. 2013. Rootstocks induce contrasting photosynthetic responses of orange plants to low night temperature without affecting the antioxidant metabolism. Theoretical and Experimental Plant Physiology 25: 26-35.

Machado, D.L.M., Lucena, C.C., Santos, D., Siqueira, D.L., Matarazzo, P.H.M., Struiving, T.B. 2011. Slow-release and organic fertilizers on early growth of Rangpur lime. Revista Ceres 58: 359-365.

Mayer, N.A., Ueno, B., Silva, V.A.L. 2015. Teores de nutrientes foliares de pessegueiro em cinco portaenxertos. Revista Brasileira de Fruticultura 37: 1045-1052.

Menegatti, R.D., Souza, A.G., Bianchi, V.J. 2019. Estimating genetic divergence between peach rootstock cultivars using multivariate techniques based on characteristics associated with seeds. Genetics and Molecular Research 1:01-10

Portes, T.A., Castro Junior, L.G. 1991. Análise de crescimento de plantas: Um programa computacional auxiliar. Revista Brasileira de Fisiologia Vegetal 3: 53-56.

Reis, J.M.R., Chalfun, N.N.J., Reis, M.A. 2010. Métodos de enxertia e ambientes na produção de mudas de pessegueiro cv. 'Diamante'. Pesquisa Agropecuária Tropical 40: 200-205.

SBCS/CQFS. Sociedade Brasileira de Ciências do Solo/ Comissão de Química e Fertilidade do Solo. 2016. Manual de adubação e de calagem para os Estados do Rio Grande do Sul e de Santa Catarina. $11^{\text {th }}$ ed. Sociedade Brasileira de Ciência do Solo/Núcleo Regional Sul, Porto Alegre, Brazil. 400 p.

Schmitz, J.D., Pasa, M.S., Fischer, D.L.O., Fachinello, J.C., Bianchi, V.J. 2014. Desempenho de porta-enxertos em diferentes sistemas de cultivo na produção de mudas do pessegueiro 'Chimarrita'. Revista Ceres 61: 293-297.

Souza, A.G., Smiderle, O.J., Menegatti, R.D., Lima, M.A.C., Neves, T.R., Bianchi, V.J. 2019. Patents for the physiological quality in seeds of peach rootstock classified by weight and stored for different periods. Recent Patents on Food, Nutrition \& Agriculture 10: 01-07.

Souza, A.G., Smirdele, O.J., Bianchi, V.J. 2018. Characterization biometric and morphophysiological of peach rootstock seeds using images of their seedling vigor. Recent Patents on Food, Nutrition \& Agriculture 10: 01-10.

Souza, A.G., Spinelli, V.M., Souza, R.O., Smiderle, O.J., Bianchi, V.J. 2017. Optimization of germination and initial quality of seedlings of Prunus persica tree rootstocks. Journal of Seed Science 39: 01-08.

Taiz, L., Zeiger, E., Moller, I.M., Murphy, A. 2017. Fisiologia e desenvolvimento vegetal. $6^{\text {th }}$ ed. Artmed, Porto Alegre, Brazil, $888 \mathrm{p}$.

Tomaz, Z.F.P., Schuch, M.W., Peil, R.M.N., Timm, C.R.F. 2014. Produção de mudas de pessegueiro via enxertia de gema ativa e dormente em sistema de cultivo sem solo. Revista Brasileira de Fruticultura 36: 1002-1008.

Viana, E.M., Kiehl, J.C. 2010. Doses de nitrogênio e potássio no crescimento do trigo. Bragantia 69: 975-982.

Conflict of Interest Statement: The authors declare that the research was conducted in the absence of any commercial or financial relationships that could be construed as a potential conflict of interest.

All the contents of this journal, except where otherwise noted, is licensed under a Creative Commons Attribution License attribuition-type BY. 